\title{
2012s-14
}

\section{News, Politics, and Negativity}

Stuart Soroka, Stephen McAdams

\begin{tabular}{c}
\hline Série Scientifique \\
Scientific Series
\end{tabular}

\section{Montréal \\ Mai 2012}

(C) 2012 Stuart Soroka, Stephen McAdams. Tous droits réservés. All rights reserved. Reproduction partielle permise avec citation du document source, incluant la notice $($.

Short sections may be quoted without explicit permission, if full credit, including (C) notice, is given to the source.

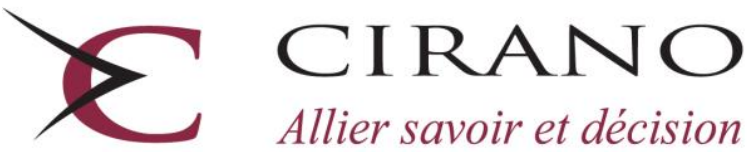

Centre interuniversitaire de recherche en analyse des organisations 


\section{CIRANO}

Le CIRANO est un organisme sans but lucratif constitué en vertu de la Loi des compagnies du Québec. Le financement de son infrastructure et de ses activités de recherche provient des cotisations de ses organisations-membres, d'une subvention d'infrastructure du Ministère du Développement économique et régional et de la Recherche, de même que des subventions et mandats obtenus par ses équipes de recherche.

CIRANO is a private non-profit organization incorporated under the Québec Companies Act. Its infrastructure and research activities are funded through fees paid by member organizations, an infrastructure grant from the Ministère du Développement économique et régional et de la Recherche, and grants and research mandates obtained by its research teams.

\section{Les partenaires du CIRANO}

\section{Partenaire majeur}

Ministère du Développement économique, de l'Innovation et de l'Exportation

\section{Partenaires corporatifs}

Autorité des marchés financiers

Banque de développement du Canada

Banque du Canada

Banque Laurentienne du Canada

Banque Nationale du Canada

Banque Royale du Canada

Banque Scotia

Bell Canada

BMO Groupe financier

Caisse de dépôt et placement du Québec

\section{CSST}

Fédération des caisses Desjardins du Québec

Financière Sun Life, Québec

Gaz Métro

Hydro-Québec

Industrie Canada

Investissements PSP

Ministère des Finances du Québec

Power Corporation du Canada

Rio Tinto Alcan

State Street Global Advisors

Transat A.T.

Ville de Montréal

\section{Partenaires universitaires}

École Polytechnique de Montréal

HEC Montréal

McGill University

Université Concordia

Université de Montréal

Université de Sherbrooke

Université du Québec

Université du Québec à Montréal

Université Laval

Le CIRANO collabore avec de nombreux centres et chaires de recherche universitaires dont on peut consulter la liste sur son site web.

Les cahiers de la série scientifique (CS) visent à rendre accessibles des résultats de recherche effectuée au CIRANO afin de susciter échanges et commentaires. Ces cahiers sont écrits dans le style des publications scientifiques. Les idées et les opinions émises sont sous l'unique responsabilité des auteurs et ne représentent pas nécessairement les positions du CIRANO ou de ses partenaires.

This paper presents research carried out at CIRANO and aims at encouraging discussion and comment. The observations and viewpoints expressed are the sole responsibility of the authors. They do not necessarily represent positions of CIRANO or its partners. 


\title{
News, Politics, and Negativity
}

\author{
Stuart Soroka ${ }^{*}$ Stephen McAdams ${ }^{\dagger}$
}

\begin{abstract}
Résumé / Abstract
Work in political communication has discussed the ongoing predominance of negative news, but has offered few convincing accounts for this focus. A growing body of literature shows that humans regularly pay more attention to negative information than to positive information, however. This paper argues that we should view the nature of news content in part as a consequence of this asymmetry bias observed in human behavior. A psychophysiological experiment capturing viewers' reactions to actual news content shows that negative news elicits stronger and more sustained reactions than does positive news. Results are discussed as they pertain to political behavior and communication, and to politics and political institutions more generally.
\end{abstract}

Mots clés / keywords : negativity bias, mass media, political communication, psychophysiology.

\footnotetext{
* Department of Political Science, McGill University. and CIRANO.

${ }^{\dagger}$ Department of Music Research, Schulich School of Music, and the Centre for Interdisciplinary Research in Music Media and Technology (CIRMMT), McGill University.
} 
News content is dominated by the negative. Consider the well-known phrases, "If it bleeds, it leads," or, "No news is good news." Or simply consider any recent newspaper or television news broadcast. That news tends to be negative is clear enough to any regular news consumer.

Political news is of course no exception. And an increasing body of work in political science suggests that this negative information may matter a great deal. Research suggests asymmetry in responses to negative versus positive information, across a wide range of domains. There is evidence that negative information plays a greater role in voting behavior, for instance; that US presidents are penalized electorally for negative economic trends but reap few electoral benefits from positive trends; asymmetries have been identified in the formation of more general impressions of US presidential candidates and parties; and the significance of negativity has been examined as it relates to the effects of negative campaigning, and declining trust in governments.

Why is there such an emphasis on negative information in mass media, and in political communications and politics more generally? This paper explores one likely answer to this question. The paper reports findings from a lab experiment in which participants view a selection of real television news stories while we monitor a number of physiological indicators, including heart rate and skin conductance. Results confirm that negative information produces a much stronger psychophysiological response than does positive information; they suggest, in short, that people are more reactive and attentive to negative news than they are to positive news.

This study demonstrates this asymmetry for the first time using real television news content. Our work thus extends existing psychophysiological research (largely outside political science) documenting asymmetric responses to positive versus negative 
information. But, just as importantly, we use the findings below to suggest an argument about the sources of negativity in news content, and politics more generally. Specifically, we use the experiment to (a) discuss the possibility that the structure of news content is intimately related to the functioning of the human brain, (b) connect observations of asymmetry in political science to existing accounts and explanations in psychology, economics, neurology and physiology, and (c) begin to more fully account for, and address the potential consequences of, negativity in political communication, political behavior, and politics.

\section{Negativity in Psychology \& Economics}

Our work is motivated in large part by bodies of literature in psychology and economics that suggest that humans respond more to negative than to positive information. Given a unit of positive information and a unit of negative information (whatever a "unit" of information might be), we often react more to the latter than to the former.

There is evidence of this negativity bias — or, more broadly, the relative strength of negative over positive - throughout psychology. Indeed, evidence of a negativity bias has been the subject of several very valuable meta-reviews (e.g., Baumeister et al. 2001; Cacioppo and Gardner 1999; Rozin and Royzman 2001). Consider first the literature on "impression formation," which suggests that in our assessment of other individuals we tend to weight negative information much more highly than positive information. ${ }^{1}$ Consider also the body of research on information processing, which suggests that people devote more cognitive energy to thinking about bad things than to thinking about

\footnotetext{
${ }^{1}$ For early work see Feldman 1966; Hodges 1974; Hamilton and Huffman 1971. For more recent work see Fiske 1980, Ronis and Lipinski 1985; Singh and Teoh 2000; Van der Pligt and Eiser 1980; Vonk 1993, 1996.
} 
good things (e.g., Abele 1985; Fiske 1980). Work on attributional processing - the process of trying to find explanations or meaning for events — suggests a similar asymmetry (e.g., Taylor 1983). And not only does negative information induce a greater degree of processing, all information is subject to more processing when the recipient is in a bad mood (e.g., Bless, Hamilton and Mackie 1992; Isen 1987; Isen et al. 1997; Scharz 1990). ${ }^{2}$ These are just some of the areas in which psychologists have found that negative information has a greater impact than positive information. ${ }^{3}$

These findings in psychology are echoed in economics, where experimental work on loss aversion suggests that people care more strongly about a loss in utility than they do about a gain of equal magnitude (Kahneman and Tversky 1979; Tversky and Kahneman 1991). Theories of loss aversion bear a close resemblance to "frequency-weight" accounts of impression formation in psychology — they too are a product of differential reactions to negative and positive information. Loss-averse behavior has been found at the individual level across a wide range of decision-making environments, both in the lab and in the

2 The implication is that there will be an especially large degree of information processing when someone in a bad mood receives bad news. See Forgas 1992.

${ }^{3}$ Consider also, for instance, work on "person memory," e.g., Ybarra and Stephen 1996; work on performance evaluations of employees and students, e.g., Ganzach 1995, Rowe 1989; work on the effects of positive versus negative events on psychological distress, e.g., Hobfoll 1988, Wells, Hobfoll and Lavin 1999; and on daily “mood," e.g., David, Green, Martin and Suls 1997. 
real world. ${ }^{4}$ It has also been evidenced in aggregate-level macroeconomic dynamics (e.g., Bowman, Minehart and Rabin 1997).

\section{Negativity in Political Science}

Is a negativity bias evident in work on politics as well? Yes, though the observation that negative information carries more weight in political decision-making has been somewhat dispersed, and spread across several sub-fields. There are some domains in which negativity has clearly received a good deal of attention, of course; there is for instance a considerable body of work on negative campaign advertising. As a discipline, however, political science has been rather slow to come around to the idea that negative information may matter more than positive information.

Nehemiah Jordan was amongst the first political scientists to consider the possibility that, in public opinion surveys on political issues, negative attitudes may matter more than positive attitudes. The first paragraph of Jordan's Discussion is relatively clear:

Actually, there is no need for a discussion. Enough data have been presented to show that the "asymmetry" between "liking" and "disliking" does exist in enough cases and has a striking enough effect to question the simple "push-pull" model of attitudes and opinions inherent in the contemporary scales we use to measure them; consequently, it merits_-in fact, demands_-further reflection and research. (Jordan 1965: 322)

\footnotetext{
${ }^{4}$ The literature is vast, but see, e.g., Tversky, Slovic and Kahneman 1990; Kahneman and Thaler 1991; Shoemaker and Kunreuther 1979; Arkes and Blumer 1985; Diamond 1988. For a partial review, see Edwards 1996.
} 
Jordan may well have been the clearest on the matter, but he was not the first to make such an observation. For instance, Campbell, Converse, Miller and Stokes noted in their seminal book, The American Voter, that "changes in the party balance are induced primarily by negative rather than positive attitudes toward the party controlling the executive branch of federal government" (1960:554-5). Nevertheless, a rather limited number of political scientists have since taken up Jordan's task.

That said, those who have searched for a negativity bias in political behavior have often found it. Perhaps the best place at which to leap into the political science literature is with the work that most clearly parallels what we have seen in psychology: work on impression formation. Klein has applied impression formation theories to survey data on US presidential evaluations. A 1991 paper finds that traits on which a respondent ranks 1984 and 1988 presidential candidates lower matter more to their overall assessment of those candidates; a subsequent paper (Klein 1996) confirms the dynamic for 1992 presidential candidates. And this role of negativity in respondents' perceptions of presidential candidates has been identified using a variety of different survey instruments. (See, esp. Lau 1982, 1985; Holbrook et al. 2001.) Similar findings exist suggesting that while midterm congressional elections are partly a referendum on the popularity of the current president, unpopularity has a much greater effect on voting decisions than does popularity (Kernell 1977). ${ }^{5}$ There is an accumulation of similar

5 Though note that these "negative voting" results have been contested by other authors, suggesting alternative hypotheses that account for the regularity with which presidents' parties lose seats in midterm elections (e.g., Hinckley 1981; Cover 1986; Born 1990). Recent work suggests a story more in line with Kernell, but based on a prospect theory account that emphasizes the relationship between disappointment with the current presidential administration and electoral turnout (Patty 2006). Aragones' (1997) work 
findings in work on economic voting as well (Bloom and Price 1975; Claggett 1986; Headrick and Lanoue 1991; Kiewet 1982; Nannestad and Paldam 1997; Soroka 2006). ${ }^{6}$

Prospect theory, loss aversion, and asymmetry more broadly construed have played an important role in a number of political science subfields. There exist several recent reviews of the political science literature informed by prospect theory (Levy 2003; McDermott 2004; Mercer 2005), focusing in particular on the successful use of loss aversion in explaining international relations. Recent work on welfare state retrenchment suggests, relatedly, that the politics of taking away benefits are quite different than are the politics of extending them (e.g., Pierson 1994, 1996).

The area of research in political science that has undoubtedly seen the most consideration, and re-consideration, of negativity effects, is political advertising. One thing is clearly not disputed: over the postwar era, and particularly over the past two decades, there has been a steady increase in negative advertising in the US (Geer 2006; Fridkin and Kenney 2004). Campaign strategists believe that negative advertising works, especially in competitive races (Able et al. 2001; Goldstein et al 2001). And negative ads are commissioned, and aired, accordingly.

Whether negative ads have the intended effect is another matter, and here there is a good deal of disagreement in the literature. There are at least two general themes: (1) does negative advertising win or lose votes?, and (2) does negative advertising attract or repel voters? Put differently, negative advertising may affect who we vote for, but it may also

suggests a related negative-reaction account for declining popularity the longer a candidate stays in office.

${ }^{6}$ These findings reflected observations in several earlier studies, including Campbell et al.'s (1960) work on electoral behavior, and Muller's (1973) study of US foreign policy. 
affect whether we vote at all. Results, many of which are incorporated into a metaanalysis by Lau et al (1999), are for both issues rather divided. ${ }^{7}$ Some of the differences across studies may be a product of very different methodologies. That said, there are some issues for which the body of evidence is somewhat more suggestive. For instance, and importantly given the current purposes, the information conveyed in negative ads is more likely to be remembered than the information conveyed in positive ads (e.g., Babbitt and Lau 1994; Kahn and Kenney 1998b). ${ }^{8}$

\section{Negativity in News}

Advertising is by no means the only communications domain in which there is a good degree of negative content. The same trend is apparent throughout media, both print and

${ }^{7}$ The literature is vast. See. e.g., Ansolabehere et al. 1994; Ansolabehere and Iyengar 1995; Bullock 1994; Hitchon et al. 1997; Martinez and Delegal 1990; Freedman and Goldstein 1999; Geer and Lau 1998; Kahn and Kenney 1999.

${ }^{8}$ Relatedly, of the studies investigating respondents' ability to remember ads generally, either positive or negative, all survey-based studies suggest that various aspects of (or candidates in) negative ads are more likely to be remembered than aspects of (or candidates in) positive ads (Brians and Watternberg 1996; Lang 1991; Newhagen and Reeves 1991; Roberts 1995; Sulfaro 1998). Lab-based experiments with undergraduates, with only one exception (Shapiro and Rieger 1992), suggest the opposite (Hitchon and Chang 1995; King et al. 1998; Kaid et al. 1992a, 1992b; Thorson et al. 1991). The difference likely has to do with the timing involved — lab experiments clearly involve much less time than do survey-based analyses. But the bulk of the real-world evidence confirms what we would expect given the literature in psychology and elsewhere: people are more attentive to negative ads. 
television. There exist content analyses showing the relatively high proportion of news content that is sensationalistic (e.g., Davie and Lee 1995; Harmon 1989; Hofstetter and Dozier 1986; Ryu 1982); and a good deal of work documenting a tendency towards negative stories as well (e.g., Diamond 1978; Fallows 1997; Just et al. 1996; Kerbel 1995; Lichter and Noyes 1995; Niven 2000; Patterson 1994; Robinson and Levy 1985; Sabato 1991).

What accounts for the apparent negativity in media content? Explanations include the administrative or financial structure of news organizations, the biases of editors or audiences, the behavior and priorities of journalists as a profession, and so on. The media “gatekeeping" literature plays a particularly prominent role here. (See Shoemaker 1991 or Shoemaker and Vos 2009 for thorough reviews.) One of the main focuses of that literature is the tendency for news to be both sensationalist and negative; a consequence not just of the preferences of individual journalists and editors, but of the entire structure of the practice of journalism, as well as of the mediums themselves - newspapers, but especially television. (See also work by Altheide and others, e.g., Altheide 1997; Ericson et al. 1989; Meyrowitz 1985.)

There is however another possible account for the nature and tone of news content: news is predominantly negative because humans are more interested in, or reactive to, negative information. The relative absence of this account in the existing literature on news content is, we believe, rather striking (though there are some exceptions, most importantly Shoemaker 1996). A principal goal of the existing work is to make more explicit, then, the role of a negativity bias — in humans, not just in journalists and editors - in accounting for biases in news content.

In sum: humans have a reasonably well-established tendency to react more strongly to negative than to positive information; it follows that news content, created by humans, 
with the goal of getting attention from other humans, will tend to be biased towards the negative. Critical to this account is evidence that news content does indeed tend to generate stronger reactions and/or greater attentiveness when it is negative. It is to an investigation of these possibilities that we now turn.

\section{The Experiment}

The goal of our experiment is to demonstrate that the kinds of asymmetries found elsewhere also apply to individuals' reactions to real network news content. In so doing, we wish to draw a clearer link between the way humans react (psychophysiologically) to information, and the way journalists (and other political actors) select or create news stories.

Based on the work reviewed above, our expectation is that participants will react quite strongly to negative information and rather little to positive information. The "reaction" we are interested in here is an emotional one - emotional, that is, as captured by physiological measures. The use of psychophysiological methods is motivated in part by recent work in political science that uses these methods to explore the possibility that there are physiological and perhaps also genetic sources of political preferences (e.g., Oxley et al. 2008; also see citations in preceding paragraph), as well as work by Annie Lang and colleagues exploring psychophysiological reactions to media messages (e.g., Lang 1995). The experimental design draws on existing work in psychology, but also on recent work in communication. ${ }^{9}$

The experiment proceeded as follows. There were 42 participants, ranging from 18 to 35 years of age, 25 male and 17 female, reporting varying degrees of media attentiveness.

\footnotetext{
${ }^{9}$ For a thorough review of psychophysiological approach in communication studies, see Ravaja 2004.
} 
Participants knew only that this was an experiment about the news, and that we would be monitoring their physiological responses as they watched. They watched a news program on their own, on a large computer monitor in a quiet room, wearing noise-canceling headphones. They were connected to a number of biosensors on one hand, on their face, and around their torso. The experiment lasted roughly 25 minutes, during which participants viewed seven news stories. Stories were separated by one minute of grey screen; there was a countdown indicated with a large white number on the grey screen for the last five seconds so respondents were not startled by the start of a new story. The experiment also began with a full two minutes of grey screen, to establish a baseline for the various physiological readings, and also to allow respondents to settle in and get used to the biosensors.

Stories were drawn from two months (mid-September to mid-November, 2009) of national evening newscasts on Global Television, one of the three major Englishlanguage broadcasters in Canada. Stories were selected on a variety of topics, political as well as general news, and covered a range of tone, from very positive to very negative. The stories were viewed and coded for tone and topic by two coders. In the end, this precoding led to the selection of nine stories: one clearly neutral, about the Toronto Film Festival, four that showed varying degrees of positivity, and four that showed varying degrees of negativity. Topics varied from healthcare policy, to employment benefits, to vaccine shortages, to murder.

All respondents saw the Toronto Film Festival story first — a neutral and relatively boring story. They were then presented with six of the eight remaining stories. Those six were randomly drawn, and randomly ordered. Not all respondents saw the same batch of stories, then; each viewed a somewhat different selection of stories, in a different order. Short descriptions of the stories are provided in Table 1. 
[Table 1 about here]

The tone of the news stories was confirmed in two different ways. First, seven of the 42 experimental participants had worked as coders in past content-analytic projects. They knew no more about the current project than the other participants, but they were asked to perform one additional task: as they viewed stories, there were asked to code each for tone, using a seven-point negative-to-positive scale. These are what we might call "expert" coders. Stories were also rated on the same 7-point scale by 52 undergraduate students, during a lecture in a 4th-year political science class. Results from both experienced coders and students are shown in the right columns of Table 1. Note that they are nearly perfectly in line - that is, both approaches confirm the initial three-fold coding of stories as either positive, negative, or neutral, and both produced similar interval-level measures of the degree of negativity or positivity.

When the experiment ended, participants filled out a short survey capturing demographics, media use preference, and past federal vote. All experiments were conducted by one of two female research assistants. (The scripts for the pre-experiment explanation and the post-experiment debriefing are available upon request.)

Physiological responses were captured using a ProComp Infiniti encoder from Thought Technology Ltd., and purpose-built software designed at the Centre for Interdisciplinary Research in Music Media and Technology (CIRMMT) at McGill University. We focus here on two responses in particular: skin conductance and heartrate.

Skin conductance (SC), reflecting the level of moisture exuded by the ecrine sweat glands, was captured by passing an infinitesimally small electrical current through a pair of electrodes on the surface of the skin — in this case, electrodes attached to the tips of the distal phalanx (outer segment) of the index and ring fingers, captured using Thought Technology's SC-Flex/Pro sensor. The current is held constant, and the electrodes 
monitor variations in current flow. More moisture (sweat) leads to less resistance, or, conversely, more conductance. The resulting conductance data can be used to look at both skin conductance levels (SCL) and skin conductance responses (SCR). The former is simply the level of conductance, measured in microSiemens. The latter is focused on the number of peaks in the SCL signal.

Variations in skin conductance are useful as an indicator of physiological arousal (Simons et al. 1999; Lang et al. 1999; Bolls et al. 2001; see review in Ravaja 2004). Note that arousal is not the same thing as valence - arousal refers only to the degree of activation, not the direction (positive or negative, pleasant or unpleasant) of the reaction (Larsen and Diener 1992; Russell 1980). But the degree of arousal is what is most critical in this experiment. We have stories, coded as positive and negative, and are interested in which ones generate the strongest reactions. The expectation is that negative stories will elicit a stronger reaction.

Heartrate was measured using a blood volume pulse (BVP) sensor, captured using Thought Technology's BVP-Flex/Pro sensor. The sensor uses photoplethysmography (measuring the amount light transmitted through the finger tissue) to detect variations in the volume of blood in the distal phalanx of the middle finger. Because the volume of blood in vessels varies with heartbeats, the resulting waveform can be used to determine heartrate. Below, heartrate is examined at 5 -second intervals.

Heartrate is often used as a measure of attentiveness, where decreasing heartrate indicates increasing attentiveness (Lang 1990; Mulder and Mulder 1981). Note, however, that existing work suggests that heartrate is not exclusively about attentiveness, but can be linked to emotional arousal as well; indeed, the literature suggests that heartrate likely reflects a combination of arousal and attentiveness. Either way, we expect that heartrate will vary systematically with the tone of news content. Specifically, 
we expect it to be lower, showing greater levels of attentiveness (and perhaps arousal as well), for negative stories.

\section{Results}

Figures 1 and 2 show results for two representative respondents. The beginning and end of stories, as well as the beginning and end of the gray-screen periods between stories, are marked with a thin vertical line. Negative stories are grayed out between those lines; positive and neutral stories are not. (Note that the two respondents see stories in a different order.)

[Figures 1 and 2 about here]

For skin conductance (SC) analyses, data are originally sampled 256 times per second, but downsampled for analysis by taking averages over $125-\mathrm{ms}$ intervals. The SC signal is smoothed slightly for analysis, using Lowess smoothing with a bandwidth of .02. Skin

conductance measures can tend to decrease over the experiment (a consequence of measurement issues with the electrodes), so the skin conductance levels (SCL) shown in the figures (and used in analyses) have also been de-trended. The SC signal is de-trended by regressing the entire time series on a count variable, capturing time in 125-ms intervals. The count variable was included in both its linear and quadratic form, allowing for the possibility of non-linear effects; predicted values were then subtracted from the original variable to produce the final de-trended series. Analyses of SCLs rely on these downsampled, smoothed, and de-trended SC series; for analyses of covariance (ANCOVAs), values are also averaged over 5-s intervals. The raw skin conductance data are shown in Figures 1 and 2 (above) as small dots; the final series used in analyses are represented by dark lines. 
Analyses of skin conductance responses (SCR) rely on the identification of peaks within this series, using a simple algorithm that identifies time points preceded and then followed by sustained (roughly 10 125-ms intervals) increases or decreases in the SC signal. These statistically-identified peaks in the SC signal are confirmed manually before preceding with the analyses. In Figures 1 and 2, small x's on that line denote SCRs.

Heartrate in Figures 1 and 2 is shown as a Lowess-smoothed trend, based on signals also downsampled to 125 -ms intervals.

We explore differences in psychophysiological reactions to negative versus positive news content using relatively simple within-respondent analyses of covariance (ANCOVA) of both SCL and Heartrate, averaged over 5-s intervals. In each case, the physiological measure is modeled as a function of the following:

(1) respondent IDs, to account for level differences in physiological symptoms across respondents;

(2) an ordinal variable representing order of presentation of the stories, to capture the possibility that respondents' reactions change based on the number of stories they have seen thus far;

(3) time (in 5-second intervals) and time squared, to capture the (potentially non-linear) tendency for both SCL and heartrate to decline slightly over the course of the experiment; and

(4) a binary variable contrasting negative with positive and neutral stories was included directly and in interaction with the time variables. The direct effect captures the possibility that negative stories produce an initial impact which is greater or lesser in 
magnitude than positive stories; the interaction with time allows for the possibility that the effect of negative stories is more (or less) long-lasting. ${ }^{10}$

Table 2 shows the basic ANCOVA results for SCRs in the left panel and the corresponding ordinary least squares (OLS) regression coefficients in the right. ${ }^{11}$ The unit of analysis here is each story for each respondent; the dependent variable is the number of identified SCRs in each story. A good deal of the respondent/story-level variance in SCRs is accounted for by differences across respondents. ${ }^{12}$ Story order does not matter to the number of SCRs. Negativity does, however: the regression coefficient shows that the effect is in the direction we would expect; that is, a negative story produces on average .38 more SCRs than does a positive story. Participants are, in short, more activated by negative stories than by positive ones.

[Table 2 about here]

Results are similar for SCL, shown in Table $3 .{ }^{13}$ Again, the model includes respondent IDs, an ordinal variable capturing story order, a variable capturing time within each story (in 5-second intervals), and a dummy variable for negative stories. The results confirm

${ }^{10}$ This and all subsequent analyses were conducted both with a simple dummy variable to capture tone, and by using the interval-level measure produced by the coders. Both work similarly in every case. For the sake of simplicity, we use the simple dummy variable here.

${ }^{11}$ Basic descriptive statistics for the dependent variable, SCRs, are as follows: mean, 1.602; standard deviation 1.326; min, 0 ; max, 7 .

12 Indeed, respondent IDs account for roughly $45 \%$ of the total variance (248.208/551.60).

${ }^{13}$ Basic descriptive statistics for the dependent variable, SCRs, are as follows: mean, 15.096; standard deviation, .344; $\min , 13.616$; max, 19.174 . 
the expectation that negativity results in a higher SCL overall, and that it reduces the tendency for respondents' SCL to gradually return to its previous value. So participants have stronger and longer reactions to negative stories than to positive stories. Coefficients show that all effects are in the expected direction.

[Tables 3 and 4 about here]

The same is true for heartrate, shown in Table $4 .{ }^{14}$ These results are based again on 5second averages, and the same model as is used for SCL. Negativity is, as we expect, associated with a decreased heartrate. This likely suggests heightened attentiveness, though recall that heartrate may actually reflect some combination of attentiveness and arousal. That there is another possibility as well: heartrate captures attentiveness alone, that attentiveness is not driven by negativity but by arousal, and arousal is driven by negativity. One way to explore this possibility with these data is to add the measure of arousal (SCL) to the ANCOVA for heartrate, to see both if SCL and heartrate are systematically related, and if negativity continues to matter to heartrate, independent of SCL. Doing so shows no significant relationship between SCL and heartrate, however and no significant changes in the other coefficients in the model either. These results offer some evidence that heartrate does indeed capture something independent of arousal. $^{15}$

[Figure 3 about here]

Results for both SCL and heartrate are made clearer in Figure 3. The figure plots the predicted levels of each measure, based on the regression models in Tables 3 and 4.

${ }^{14}$ Basic descriptive statistics for the dependent variable, SCRs, are as follows: mean, 76.197; standard deviation 13.330; min, 30.782; $\max , 167.612$.

${ }^{15}$ Results are available upon request. 
Note the difference between positive and negative stories in each case. Negative stories are associated with lower heartrate (more attention) and increased SCL (more activation); positive stories are associated with higher heartrate (less attention) and smaller increases in SCL (less activation). (Note that the impact of story tone on SCL is as follows: all stories seem to produce a certain degree of arousal to start, but positive stories show more steeply declining SCL.) All indications are that participants are more aroused by, and pay more attention to, negative stories.

\section{Discussion \& Conclusions}

Our experiment shows, using for the first time actual network news broadcasts, that participants react more strongly to negative than to positive news content. Viewed from a media effects perspective, the implication is that negative news content is likely to have a greater, and possibly more enduring, impact than is positive news content. This is in line with work on negative political advertising, as well as with a diverse body of work in political behavior, communication, and other fields (reviewed above). Our demonstration makes clear that the asymmetry carries over to regular news content as well.

In so doing, our results highlight one often overlooked psychophysiological account for the focus on negative information in news media, and indeed in communications, behavior, and political affairs more generally. This account is, we believe, much more convincing than what seems to be the implicit, popularized argument about political news, and indeed news more generally — that journalists or editors are just cynical people, drawn to present negative news whenever possible. (The same has been said of politicians and party strategists, of course.) 
There is also a rather more ambitious, or at least more conjectural, interpretation of these findings. It seems likely, in short, that evolution favors animals that exhibit a combination of mildly optimistic and loss-averse behavior. The standard account is roughly as follows: you have to be willing to try new food sources, but if your friend is poisoned in the process you need to be the animal that does not try that food again. Put more scientifically, work on "orienting responses" suggests that evolution has produced animals with attentional systems that give preference to stimuli with adaptive significance (Ohman et al. 1998; Hunt and Campbell 1997). Foremost amongst those stimuli are signs of danger. And, "because it is more difficult to reverse the consequences of an injurious or fatal assault than those of an opportunity unpursued, the process of natural selection may also have resulted in the propensity to react more strongly to negative than to positive stimuli" (Cacioppo \& Gardner 1999; see also the discussion in Herwig et al. 2007). ${ }^{16}$

This role of evolutionary processes in the negativity bias has been noted in other fields, including work exploring the tendency for neurological reactions to be greater in magnitude for negative than for positive events (e.g., Smith et al. 2002), ${ }^{17}$ and work in physiology on, for instance, the "fight or flight" reaction to negative events, which leads

${ }^{16}$ The idea that a negativity bias may be a product of evolution is by no means recent. See Darwin (1872), and a useful discussion of Darwin's work in Fridlund (1991).

${ }^{17}$ Research also points towards a brain mechanism the role of which is specifically to detect self-generated errors. Neurologists believe that the anterior cingulate in the frontal lobe of the brain plays an important role in pain perception and self-regulation, including the monitoring of error responses. For a review, see Luu, Collins and Tucker 2000; Dehaene, Posner and Tucker 1994; Gehring et al. 1993; Miltner, Braum and Coles 1997). 
to heightened heart rate, blood pressure and perspiration, and prepares the organism for either fighting or fleeing (Cannon 1932). ${ }^{18}$ The evolutionary account is supported by a body of work finding evidence of a negativity bias in animals other than humans (e.g., Miller 1961; Garcia and Koelling 1966; Hodge and Stockin 1912; Warden and Aylesworth 1927; Mahl 1952; Brosnan et al. 2007). It has been suggested as an explanation for negativity in news content by Shoemaker (1996), among the first to highlight a potential relationship between theories of evolution and accounts of media content. ${ }^{19}$ It is also in line, generally speaking, with a growing, and fascinating, body of work in political science interested in finding physiological as well as genetic accounts for political behavior (e.g., Alford and Hibbing 2004; Alford et al. 2005; Fowler et al. 2009; Hatemi et al. 2010a, 2010b. 2009; Smith et al. 2007).

All of this said, we cannot of course demonstrate that our results are a product of evolution. We wish only to highlight this possible connection between what we have identified here, and what others have identified in related fields. And importantly, we do not require an evolutionary account to make our results interesting or important to the study of political psychology and political communication. That humans react more strongly to negative news content is on its own enough - enough, that is, to lead to a serious reconsideration of how and why negative news is so prevalent.

Returning to that theme, then, note that the propensity to over-represent negativity in mass media need not be a product of profit-maximization alone. Journalists and editors are also humans, after all, and thus have the same tendencies as their audience. Moreover, the design of mass media as an institution likely predisposes media towards focusing on the negative. One of main functions of media in a democracy is holding

\footnotetext{
${ }^{18}$ See Rozin and Royzman's (2001) review of the literature.

${ }^{19}$ See also Fuller 2010, and the the discussion of Shoemaker's work in Ju 2008.
} 
current Governments (and companies, and indeed some individuals) accountable. This notion of mass media as a "Fourth Estate" (Carlyle 1841) has been prominent both in the literature on newspapers (e.g., Merrill and Lowenstein 1971; Hage et al. 1976; Small 1972), as well as in the pages of newspapers themselves. Surveillance of this kind mainly involves identifying problems. We might consequently expect that media emphasize negative information in part because it is their job to do so. Indeed, we might expect this of a wide range of political institutions.

This link between the human brain and the functioning not just of political communications, but of political institutions, is a potentially fruitful line of analysis for future work. Our brains tend to focus on error identification and error correction; our legislative institutions, both parliamentary and presidential, tend to do the same. While the negativity bias is perhaps most easily demonstrated in political communication, then, we believe it has much broader implications.

There is certainly more work to be done with these, or similar, psychophysiological data. For instance, recent work points towards the possibility that participant traits, including partisanship, affect psychophysiological responses to negative information (e.g., Alford et al. 2005, Hatemi et al. 2010). For the time being, however, this paper has focused on a simple, but we believe profound, hypothesis; namely, that negative news elicits quite different (i.e., stronger and longer) reactions from media consumers than does positive news. Evidence here suggests that it does, and in so doing it suggests a psychophysiological explanation for the focus on negative information in mass media: it is more arousing and attention grabbing. We suspect our results point towards an evolutionary account for the nature of news content. They may point towards an evolutionary account for the (negative) nature of politics more broadly as well. 


\section{Bibliography}

Abele, A. 1985. "Thinking about thinking: Causal, evaluative, and finalistic cognitions about social situations.” European Journal of Social Psychology 15: 315-332.

Able, O. G., Herrnson, P. S., Magleby, D. B., \& Patterson, K. 2001. “Are professional campaigns more negative?” In P. S. Herrnson (Ed.), Playing hardball: Campaigning for the U.S. Congress. Upper Saddle River, NJ: Prentice Hall.

Alford, John R. and John R. Hibbing. 2004. "The Origin of Politics: An Evolutionary Theory of Political Behavior.” Perspectives on Politics 2: 707-23.

Alford, John, Carolyn Funk, and John R. Hibbing. 2005. “Are Political Orientations Genetically Transmitted.” American Political Science Review 99: 153-66.

Altheide, David L. 1997. "The News Media, the Problem Frame, and the Production of Fear.” Sociological Quarterly 38(4): 647-68.

Ansolabehere, Stephen, Shanto Iyengar, Adam Simon, and Nicholas Valentino. 1994. “Does Attack Advertising Demobilize the Electorate?" American Political Science Review 88: 829-38.

Ansolabehere, Stephen, and Shanto Iyengar. 1995. Going Negative: How Political Advertisements Shrink and Polarize the Electorate. New York: Free Press.

Aragones, Enriqueta. 1997. "Negativity Effect and the Emergence of Ideologies." Journal of Theoretical Politics 9(2): 189-210.

Arkes, H.R. and C. Blumer. 1985. "The psychology of sunk cost." Organizational Behavior and Decision Processes 5: 124-140.

Babbitt, Paul R., and Richard R. Lau. 1994. "The Impact of Negative Political Campaigns on Political Knowledge." Paper presented at the annual meeting of the Southern Political Science Association, Atlanta. 
Bless, H., Hamilton, D. L., \& Mackie, D. M. 1992. "Mood effects on the organization of person information.” European Journal of Social Psychology 22: 497-509.

Born, Richard 1990. "Surge and Decline, Negative Voting, and the Midterm Loss Phenomenon: A Simultaneous Choice Analysis.” American Journal of Political Science 34(3): 615-45.

Bowman, David, Deborah Minehart and Matthew Rabin. 1999. "Loss Aversion in a Consumption- Savings Model." Journal of Economic Behavior and Organization 38: 155-78.

Bloom, H. S., H. D. Price. 1975. "Voter Response to Short-Run Economic Conditions: The Asymmetric Effect of Prosperity and Recession." American Political Science Review 69: 1240-54.

Bolls, Paul D., Annie Lang and Robert F. Potter. 2001. "The Effects of Message Valence and Listener Arousal on Attention, Memory, and Facial Muscular Responses to Radio Advertisements." Communication Research 28(5): 627-651.

Brians, Craig L., and Martin P. Wattenberg. 1996. "CampaignIssue Knowledge and Salience: Comparing Reception from TV Commercials, TV News, and Newspapers." American Journal of Political Science 40: 172-93.

Brosnon, Sarah F., Owen D. Jones, Susan P. Lambeth, March Catherine Mareno, Amanda S. Richardson and Steven J. Schpiro. 2007. "Endowment Effects in Chimpanzees.” Current Biology 17: 1704-1707.

Bullock, David A. 1994. "The Influence of Political Attack Advertising on Undecided Voters:An Experimental Study of Campaign Message Strategy.” Ph.D. diss. University of Arizona.

Cacioppo J.T., W.L. Gardner. 1999. "Emotion.” Annual Review of Psychology 50:191214. 
Cannon, W. B. 1932. The Wisdom of the Body. New York: Norton.

Claggett, William. 1986. "A Reexamination of the Asymmetry Hypothesis: Economic Expansions, Contractions, and Congressional Elections.” Western Political Quarterly 39(4): 623-33.

Cover, Albert D. 1986. "Presidential Evaluations and Voting for Congress." American Journal of Political Science 30: 786-801.

Darwin, C., 1872. The Expression of the Emotions in Man and Animals. London: J. Murray.

David, J. P., Green, P. J., Martin, R., \& Suls, J. 1997. "Differential roles of neuroticism, extraversion, and event desirability for mood in daily life: An integrative model of topdown and bottom-up influences." Journal of Personality and Social Psychology 73: $149-159$.

Davie, William R., and Jung Sook Lee. 1995. "Sex, Violence, and Consonance/Differentiation: An Analysis of Local TV News Values.” Journalism and Mass Communication Quarterly 72(1): 128-38.

Dawson, Michael E., Annie M. Schell and Diane L. Filion. 2007. "The Electrodermal System.” Pp. 159-181 in John Cacioppo, Louis G. Tassinary and Gary G. Berntson, eds., The Handbook of Psychophysiology. Cambridge: Cambride University Press.

Dehaene, S., Posner, M. I., \& Tucker, D. M. 1994. "Localization of a neural system for error detection and compensation.” Psychological Science 5: 303-305.

Diamond, Edwin. 1978. Good News, Bad News. Cambridge: MIT Press.

Diamond, W.D. 1988. "The effect of probability and consequence levels on the focus of consumer judgements in risky situations.” Journal of Consumer Research 5: 280-283.

Edwards, Kimberly. 1996. "Prospect Theory: A Literature Review." International Review of Financial Analysis 5(1): 19-38. 
Ericson, Richard, Patricia Baranek and Janet Chan. 1987. Visualizing Deviance: A Study of News Organization. Toronto: University of Toronto Press.

Fallows, James. 1997. Breaking the News. New York: Vintage

Feldman, S. 1966. "Motivational aspects of attitudinal elements and their place in cognitive interaction.” Pp. $75-108$ in S. Feldman (Ed.), Cognitive Consistency: Motivational Antecedents and Behavioral Consequences. New York: Academic Press

Fiske, S. T. 1980. "Attention and weight in person perception: The impact of negative and extreme behavior.” Journal of Personality and Social Psychology 38: 889-906.

Forgas, J. P. 1992. "Mood and the perception of unusual people: Affective asymmetry in memory and social judgments.” European Journal of Social Psychology 22: 531-547.

Fowler, James H. Christopher T. Dawes, and Nicholas A. Christakis. 2009. "Model of genetic variation in human social networks.” Science 106(6): 1720-1724.

Freedman, P., \& Goldstein, K. M. 1999. "Measuring media exposure and the effects of negative campaign ads.” American Journal of Political Science 43(4): 1189-1208.

Fridkin, Kim Leslie, and Patrick J. Kenney. 2004. "Do Negative Messages Work? The Impact of Negativity on Citizens' Evaluations of Candidates." American Politics Research 32(5): 570-605.

Fridlund, A.J., 1991. "Evolution and facial action in reflex, social motive, and paralanguage.” Biological Psychology 32(1): 3-100.

Fuller, Jack. 2010. What is Happening to News: The Information Explosion and the Crisis in Journalism. Chicago: University of Chicago Press.

A. Ganzach Y. 1995. "Negativity (and positivity) in performance evaluation: three field studies.” Journal of Applied Psychology 80:491-99.

Garcia, J., \& Koelling, R. A. 1966. "Relation of cue to consequence in avoidance learning." Psychonomic Science 4: 123-124. 
Geer, John G. 2006. In Defense of Negativity: Attack Ads in Presidential Campaigns. Chicago: University of Chicago Press.

Geer, John G. and Richard R. Lau. 1998. "A New Way to Model the Effects of Campaigns." Paper presented at the annual meeting of the American Political Science Association, Boston.

Gehring, W. J., Goss, B., Coles, M. G. H., Meyer, D. E., \& Donchin, E. 1993. “A neural system for error detection and compensation.” Psychological Science 4: 385-390.

Goldstein, K. M., Krasno, J. S., Bradford, L., \& Seltz, D. E. (2001). “Going negative: Attack advertising in the 1998 elections." In Paul S. Herrnson (Ed.), Playing hardball: Campaigning.

Hamilton, D. L., \& Huffman, L. J. 1971. "Generality of impression formation processes for evaluative and nonevaluative judgments." Journal of Personality and Social Psychology 20: 200-207.

Harmon, Mark D. 1989. “Market Size and Local Television News Judgment.” Journal of Media Economics 2: 15-29

Hatemi, Peter K. et al. 2010. “A Genome-Wide Analysis of Liberal and Conservative Political Attitudes.” Journal of Politics (forthcoming).

Hatemi, Peter K., J.R. Hibbing, S.E. Medland, M.C. Keller, J.R. Alford, N.G. Martin, L.J. Eaves. 2010. "Not by Twins Alone: Using the Extended Twin Family Designed to Investigate the Genetic Basis of Political Beliefs." American Journal of Political Science 54(3):798-814.

Hatemi, Peter K., Carolyn Funk, Hermine Maes, Judy Silberg, Sarah Medland, Nicholas Martin and Lindon Eaves. 2009. "Genetic Influences on Social Attitudes over the Life Course.” Journal of Politics 71(3): 1141-1156. 
Headrick, Barbara, and David J. Lanoue. 1991. “Attention, Asymmetry, and Government Popularity in Britain.” Political Research Quarterly 44 (1): 67-86.

Herwig, Uwe, Tina Kaffenberger, Thomas Buamgartner and Luzt Jancke. 2007. "Neural correlates of a 'pessimistic' attitude when anticipating events of unknown emotional valence." NeuroImage 34: 848-858.

Hinckley, Barbara. 1981. Congressional Elections. Washington DC: Congressional Quarterly Press.

Hitchon, Jacqueline C., Chingching Chang, and Rhonda Harris. 1997. "Should Women Emote? Perceptual Bias and Opinion Change in Response to Political Ads for Candidates of Different Genders.” Political Communication 14: 49-69.

Hitchon, Jacqueline C., and Chingching Chang. 1995. "Effects of Gender Schematic Processing on the Reception of Political Commercials for Men and Women Candidates." Communication Research 22: 430-58.

Hobfoll, S.E. 1988. The Ecology of Stress. Washington, DC: Hemisphere.

Hodge, M.A., R.J. Stocking. 1912. "A note on the relative value of punishment and reward as motives.” Animal Behavior 2: 43-50.

Hodges, B. H. 1974. "Effect of valence on relative weighting in impression formation." Journal of Personality and Social Psychology 30: 378-381.

Hofstetter, C. Richard and David M. Dozier. 1986. "Useful News, Sensational News: Quality, Sensationalism and Local TV News.” Journalism Quarterly 63: 815-20, 853.

Holbrook, Allyson L., Jon A. Krosnick, Penny S. Visser, Wendi L. Gardner, and John T. Cacioppo. 2001. "Attitudes toward Presidential Candidates and Political Parties: Initial Optimism, Inertial First Impressions, and a Focus on Flaws." American Journal of Political Science 45 (4): 930-50. 
Hunt PS, Campbell BA. 1997. "Autonomic and behavioral correlates of appetitive conditioning in rats". Behavioral Neuroscience 111:494-502

Isen, A. M. 1987. 'Positive affect, cognitive processes, and social behavior'. Pp. 203-253 in Berkowitz, L. (Ed.) Advances in Experimental Social Psychology, Vol. 20. San Diego: Academic Press.

Isen, A. M., Daubman, K. A. and Gorgoglione, J. M. 1987. "The influence of positive affect on cognitive organization." Pp. 143-164 in Snow, R. and Farr, M. (Eds) Aptitude, Learning and Instruction: Affective and Cognitive Processes, Vol. 3. Hillsdale NJ: Erlbaum.

Jordan, Nehemaih. 1965. "The Asymmetry of Liking and Disliking: A Phenomenon Meriting Further Reflection and Research.” Public Opinion Quarterly 29: 315-22.

Just, Marion R., Ann N. Crigler, and W. Russell Neuman. 1996. "Cognitive and Affective Dimensions of Political Conceptualization.” In The Psychology of Political Communication, ed. Ann N. Crigler. Ann Arbor: University of Michigan Press.

Kaid, Lynda Lee, Mike Chanslor, and Mark Hovind. 1992. "The Influence of Program and Commercial Type on Political Advertising Effectiveness.” Journal of Broadcasting and Electronic Media 36:303-20.

Kahn, Kim Fridkin, and Patrick J. Kenney. 1998. "Negative Advertising and an Informed Electorate: How Negative Campaigning Enhances Knowledge of Senate Elections." Paper presented at the Conference on Political Advertising in Election Campaigns, Washington, DC.

Kahn, Kim Fridkin, and Patrick J. Kenney. 1999. "Do Negative Campaigns Mobilize or Suppress Turnout? Clarifying the Rela- tionship between Negativity and Participation." American Political Science Review 93: 877-89. 
Kahneman, Daniel, and Amos Tversky. 1979. "Prospect Theory: An Analysis of Decision Under Risk.” Econometrica 47(2): 263-92.

Kahneman, D. and R. Thaler. 1991. "Economic-analysis and the psychology of utility — applications to compensation policy.” American Economic Review 81: 341-346.

Kerbel, Matthew. 1995. Remote and Controlled. Boulder, Colo.: Westview Press.

Kernell, Samuel. 1977. "Presidential Popularity and Negative Voting: An Alternative Explanation of the Midterm Congressional Decline of the President's Party.” American Political Science Review 71 (1): 44-66.

Kiewiet, D. Roderick. 1983. Macroeconomic and Micropolitics: The Electoral Effects of Economic Issues. Chicago: University of Chicago Press.

Klein J.G. 1991. "Negativity effects in impression formation: a test in the political arena." Personality Soc. Psychological Bulletin 17:412-18.

Lang, Annie. 1995. What can the heart tell us about thinking? Pp. 99-112 In A. Lang (Ed.), Measuring Psychological Responses to Media. Hillsdale, NJ: Lawrence Erlbaum. —. 1991. "Emotion, Formal Features, and Memory for Televised Political Advertisements." Pp. 221-44 in Frank Biocca, ed., Television and Political Advertising, Vol. 1. Hillsdale, NJ: Lawrence Erlbaum.

. 1990. "Involuntary attention and physiological arousal evoked by structural features and emotional content in TV commercials." Communication Research 17: $275-299$.

Lang, A., P. Bolls, R. F. Potter, K. Kawahara. 1999. "The effects of production pacing and arousing content on the information processing of television messages." Journal of Broadcasting and Electronic Media 43: 451-475. 
Lang, A., Dhillon, K., \& Dong, Q. 1995. "The effects of emotional arousal and valence on television viewers' cognitive capacity and memory." Journal of Broadcasting and Electronic Media 39: 313-327.

Lang, A., Newhagen, J. \& Reeves, B. 1996. "Negative video as structure: Emotion, attention, capacity, and memory." Journal of Broadcasting and Electronic Media 40: 460-477.

Lang, A., Zhou, S., Schwartz, N., Bolls, P. D., \& Potter, R. F. 2000. "The effects of edits on arousal, attention, and memory for television messages: When an edit is an edit can an edit be too much?" Journal of Broadcasting \& Electronic Media 44: 94-109.

Larsen, R. J., \& Diener, E. 1992. "Promises and problems with the circumplex model of emotion." Pp. 25-59 in M. Clark, ed., Review of Personality and Social Psychology, Vol. 13. Newbury Park, CA: Sage.

Lau, Richard R. 1985. "Two Explanations for Negativity Effects in Political Behavior." American Journal of Political Science 29(1): 119-38.

— 1982. "Negativity in Political Perception.” Political Behavior 4(4): 353-77.

—. 1984. "Dynamics of the attribution process." Journal of Personality and Social Psychology 46: 1017-1028.

Lau, Richard, Sigelman, L., Heldman, C., \& Babbitt, P. 1999. "The effects of negative political advertisements: A meta-analytic assessment." American Political Science Review 93: 851-876.

Lichter, S. Robert and Richard Noyes. 1995. Good Intentions Make Bad News. Lanham MD: Rowman and Littlefield.

Luu, P., Collins, P., \& Tucker, D. M. 2000. "Mood, Personality, and Self-Monitoring: Negative Affect and Emotionality in Relation to Frontal Lobe Mechanisms of Error Monitoring.” Journal of Experimental Psychology: General 129: 43-60. 
Mahl, G. F. 1952. "Relationship between acute and chronic fear and the gastric acidity and blood sugar levels in Macaca mulatta monkeys." Psychosomatic Medicine 14: $182-210$.

Martinez, Michael D., and Tad Delegal. 1990. "The Irrelevance of Negative Campaigns to Political Trust: Experimental and Survey Results." Political Communication and Persuasion 7: 25-40.

Mauss, M. [1902.] 1972. A General Theory of Magic. New York: W.W. Norton.

McDermott, Rose 2004. "Prospect theory in Political Science: Gains and Losses from the First Decade." Political Psychology 25(2): 289-312.

Meffert, Michael F., Sungeun Chung, Amber J. Joiner, Leah Waks \& Jennifer Garst. 2006. "The Effects of Negativity and Motivated Information Processing During a Political Campaign.” Journal of Communication 56: 27-51.

Mercer, Jonathan. 2005. "Prospect Theory and Political Science." Annual Review of Political Science 8: 1-21.

Meyrowitz, Joshua. 1985. No Sense of Place: The Impact of Electronic Media on Social Behavior. New York: Oxford University Press.

Miller NE. 1961. "Some recent studies on conflict behavior and drugs." American Psychology 16:12-24.

Miltner, W. H. R., Braun, C. H., \& Coles, M. G. H. 1997. "Event-Related Brain Potentials Following Incorrect Feedback in a Time-Estimation Task: Evidence for a “Generic" Neural System for Error Detection.” Journal of Cognitive Neuroscience 9: 788-798.

Mueller, John E. 1973. War, Presidents and Public Opinion. New York: John Wiley and Sons. 
Mulder, G., \& Mulder, L. J. 1981. "Information Processing and Cardiovascular Control.” Psychophysiology 18: 392-402.

Nannestad, Peter, and Martin Paldam. 1997. "The Grievance Asymmetry Revisited: A Micro Study of Economic Voting in Denmark, 1986-92.” European Journal of Political Economy 13(1): 81-99.

Newhagen, John E., and Byron Reeves. 1991. "Emotion and Memory Responses for Negative Political Advertising: A Study of Television Commercials Used in the 1988 Presidential Election.” Pp. 197-220 in Frank Biocca, ed., Television and Political Advertising, Vol. 1, Hillsdale, NJ: Lawrence Erlbaum..

Niven, David. 2000. "The Other Side of Optimism: High Expectations and the Rejection of Status Quo.” Political Behavior 22(1): 71-88.

Ohman A, Hamm A, Hugdahl K. 1998. "Cognition and the Autonomic Nervous System: Orienting, Anticipation, and Conditioning. See Cacioppo et al 1998. In press.

Oxley, Douglas R., Kevin B. Smith, John R. Alford, Matthew V. Hibbing, Jennifer L. Miller, Mario Scalora, Peter K. Hatemi, John R. Hibbing. 2008. "Political Attitudes Vary with Physiological Traits.” Science 321, no. 5896: 1667-1670.

Patterson, Thomas. 1994. Out of Order. New York: Vintage.

Patty, John W. 2006. "Loss Aversion, Presidential Responsibility, and Midterm Congressional Elections.” Electoral Studies 25: 227-247.

Pierson, P. 1996. “The New Politics of the Welfare State.” World Politics 48: 143-179.

Pierson P. 1994. Dismantling the Welfare State? Reagan, Thatcher, and the Politics of Retrenchment. New York: Cambridge Univ. Press

Ravaja, Niklas. 2004. "Contributions of Psychophysiology to Media Research: Review and Recommendations.” Media Psychology 6(2): 193-235. 
Roberts, Marilyn S. 1995. "Political Advertising: Strategies for Influence.” Pp. 179-99 in Kathleen E. Kendall, ed., Presidential Campaign Discourse: Strategic Communication Problems. Albany: SUNY Press.

Robinson, John and Michael Levy. 1985. The Main Source: Learning from Television News. Beverly Hills CA: Sage.

Ronis, David L., and Edmund R. Lipinski. 1985. "Value and Uncertainty as Weighting Factor in Impression Formation." Journal of Experimental Social Psychology 21(1): $47-60$.

Rowe PM. 1989. “Unfavorable Information and Interview Decisions.” Pp. 77-89 in R.W. Eder and G.R. Ferris, eds., The Employment Interview: Theory, Research, and Practice. Newbury Park, CA: Sage

Rozin, Paul and Edward B. Royzman. 2001. "Negativity Bias, Negativity Dominance, and Contagion.” Personality and Social Psychology Review 5(4): 296-320.

Russell, James A. 1980. “A Circumplex Model of Affect.” Journal of Personality and Social Psychology 39(6): 1161-1178,

Ryu, Jung S., "Public Affairs and Sensationalism in Local TV News Programs." Journalism Quarterly 59: 74-77,137.

Sabato, Larry, 1991. Feeding Frenzy. New York: Free Press.

Schwarz, N. 1990. "Feelings as information: Informational and motivational functions of affective states.” Pp. 527-561 in E. T. Higgins \& R. M. Sorrentino, eds., The Handbook of Motivation and Cognition: Foundations of Social Behavior, Vol. 2. New York: Guilford Press.

Shapiro, Michael A., and Robert H. Rieger. 1992. "Comparing Positive and Negative Political Advertising on Radio.” Journalism Quarterly 69: 135-45. 
Schoemaker, P. J. H. \& Kunreuther, H. C. 1979. “An Experimental Study of Insurance Decisions.” Journal of Risk and Insurance 46: 603-618.

Shoemaker, Pamela J. 1996. "Media Gatekeeping.” In Michael B Salwen and Don W. Stacks, eds,. An Integrated Approach to Communication Theory and Research. Mahwah, NJ: Lawrence Erlbaum. 1991. Gatekeeping. Newburry Park, CA: Sage Publications.

Shoemaker, Pamela J. and Tim P. Vos. 2009. Gatekeeping Theory. New York: Routledge.

Simons, R. F., Detenber, B. H., Roedema, T. M., \& Reiss, J. E. 1999. "Emotion Processing in Three Systems: The Medium and the Message.” Psychophysiology 36: 619-627.

Singh, R., and J.B.P. Teoh. 2000. "Impression Formation from Intellectual and Social Traits: Evidence for Behavioural Adaptation and Cognitive Processing." British Journal of Social Psychology 39(4): 537-54.

Smith, Kevin B., Levente Littvay, Chris Larimer and John R. Hibbing. 2007. "Evolutionary Theory and Political Leadership: Why People Usually Do Not Trust Decision-Makers.” Journal of Politics 69: 285-99.

Soroka, Stuart. 2006. "Good News and Bad News: Asymmetric Responses to Economic Information.” The Journal of Politics 68(2): 372-385.

Soroka, Stuart and Blake Andrew. 2009. "Media Coverage of Canadian Elections: Horse-Race Coverage and Negativity in Election Campaigns," Pp. 113-128 in Linda Trimble and Shanon Sampert, eds., Mediating Canadian Politics. Toronto: Pearson.

Soroka, Stuart, Marc Andre Bodet, Lori Young and Blake Andrew. 2009. "Campaign News and Vote Intentions." Journal of Elections, Public Opinion and Parties 19(4): 359-376. 
Taylor, S. E. 1983. “Adjustment to Threatening Events: A Theory of Cognitive Adaptation.” American Psychologist 38: 1161-1173.

Thorson, Esther, William G. Christ, and Clarke Caywood. 1991. "Selling Candidates Like Tubes of Toothpaste: Is the Comparison Apt?” Pp. 145-72 in Frank Biocca, ed., Television and Political Advertising, Vol. 1. Hillsdale, NJ: Lawrence Erlbaum.

Tversky, A. and D. Kahneman. 1991. "Loss Aversion in Riskless Choice: A Reference dependent Model.” Quarterly Journal of Economics 41: 1039-1061.

Tversky, A., Slovic, P., \& Kahneman, D. 1990. “The causes of preference reversal.” The American Economic Review 80: 204-217.

Van der Pligt, Joop, and J. Richard Eiser. 1980. "Negativity and Descriptive Extremity in Impression Formation.” European Journal of Social Psychology 10(4): 415-19.

Vonk, Roos. 1993. "The Negativity Effect in Trait Ratings and in Open-Ended Description of Persons.” Personality and Social Psychology Bulletin 19(3): 269-78.

Vonk, Roos. 1996. "Negativity and Potency Effects in Impression Formation.” European Journal of Social Psychology 26(6): 851-65.

Warden, C.J. and M. Aylesworth. 1927. "The relative value of reward and punishment in the formation of a visual discrimination habit in the white rat." Comparative Psychology 7: 117-127.

Weinberg, G. M. 1975. An Introduction to General Systems Thinking. New York: Wiley.

Wells, J. D., Hobfoll, S. E., \& Lavin, J. 1999. "When it Rains, it Pours: The Greater Impact of Resource Loss Compared to Gain on Psychological Distress.” Personality and Social Psychology Bulletin 25: 1172-118. 
Table 1. Story Descriptions and Codes

\begin{tabular}{|c|c|c|c|}
\hline \multirow[t]{2}{*}{ Title } & \multirow[t]{2}{*}{ Description } & \multicolumn{2}{|c|}{ Coded Tone ${ }^{a}$} \\
\hline & & Experts & Students \\
\hline \multicolumn{4}{|l|}{ Neutral } \\
\hline Toronto Film Festival & $\begin{array}{l}\text { filmmakers and actors arriving for the Toronto } \\
\text { International Film Festival }\end{array}$ & $0.50(.22)$ & $.096(1.35)$ \\
\hline \multicolumn{4}{|l|}{ Positive } \\
\hline Ambassador Doer & $\begin{array}{l}\text { Gary Doer, former Manitoba Premier, now taking } \\
\text { over as Canadian ambassador to the US }\end{array}$ & $1.00(.52)$ & $1.06(.80)$ \\
\hline Cancer Child & $\begin{array}{l}\text { an "Everyday Hero" story about a boy who survived } \\
\text { leukemia, and now raises money to provide video } \\
\text { games for children stuck in hospitals for cancer } \\
\text { treatment }\end{array}$ & $2.83(.17)$ & $2.61(.69)$ \\
\hline Tuition-Free Schools & $\begin{array}{l}\text { a man who raises money from corporations to build } \\
\text { tuition-free training schools in the US, coming to do } \\
\text { the same in Canada }\end{array}$ & $2.00(.26)$ & $1.65(.81)$ \\
\hline El Benefits & $\begin{array}{l}\text { the extension of Employment Insurance benefits to } \\
\text { self-employed Canadians, many of whom will now } \\
\text { be able to claim benefits such as maternity and sick } \\
\text { leave }\end{array}$ & $1.50(.22)$ & $.81(1.28)$ \\
\hline \multicolumn{4}{|l|}{$\overline{\text { Negative }}$} \\
\hline Baby Assaulted & $\begin{array}{l}\text { a recent case in which a neighbor saw and reported } \\
\text { a mother who was smashing her baby's head on the } \\
\text { sidewalk }\end{array}$ & $-2.50(.50)$ & $-2.21(1.13)$ \\
\hline Vaccine Shortages & $\begin{array}{l}\text { potential shortages in } \mathrm{H} 1 \mathrm{~N} 1 \text { vaccines, and the } \\
\text { federal government's role in those shortages }\end{array}$ & $-2.00(.37)$ & $-1.42(1.16)$ \\
\hline Afghan War & $\begin{array}{l}\text { "Are we winning?" the war in Afghanistan, focusing } \\
\text { on the relative lack of success thus far in Canadian } \\
\text { military's ongoing mission there }\end{array}$ & $-1.50(.22)$ & $-1.62(1.16)$ \\
\hline Food Banks & $\begin{array}{l}\text { how current economic circumstances mean that } \\
\text { donations to food banks have declined, even as } \\
\text { more people need to come to food banks }\end{array}$ & $-1.67(.42)$ & $-.88(1.10)$ \\
\hline
\end{tabular}

${ }^{a}$ Tone was coded by (a) a subset of experimental participants $(\mathrm{N}=7)$ and (b) a larger student sample $(\mathrm{N}=52)$, on a scale from -3 to +3 , where low scores are negative and high scores are positive. Cells contain mean scores with standard errors in parentheses. 
Table 2. Within-Respondent ANCOVA: Skin Conductance Responses

\begin{tabular}{|c|c|c|c|c|c|}
\hline \multicolumn{4}{|c|}{ ANCOVA } & \multicolumn{2}{|c|}{ OLS Regression } \\
\hline & Partial SS & df & $\mathrm{F}$ & & Raw Coef \\
\hline Model & 259.769 & 40 & $5.13^{* * *}$ & & \\
\hline Respondent & 248.208 & 38 & $5.16^{* * *}$ & & \\
\hline Order (c) & 2.220 & 1 & 1.75 & Order (c) & $-.053(.040)$ \\
\hline Negative & 8.225 & 1 & $6.50^{* * *}$ & Negative & $.377(.148)$ \\
\hline Residual & 251.831 & 199 & & Constant & $.600(.458)$ \\
\hline Total & 511.60 & 239 & & Rsq & .508 \\
\hline
\end{tabular}


Table 3. Within-Respondent ANCOVA: Skin Conductance Levels

\begin{tabular}{|c|c|c|c|c|c|}
\hline \multicolumn{4}{|c|}{ ANCOVA } & \multicolumn{2}{|c|}{ OLS Regression } \\
\hline & Partial SS & $d f$ & $\mathrm{~F}$ & & Raw Coef \\
\hline Model & 559.415 & 44 & $18.45^{* * *}$ & & \\
\hline Respondent & 158.952 & 38 & $6.07^{* * *}$ & & \\
\hline Order (c) & 4.584 & 1 & $6.65^{* *}$ & Order (c) & $.014(.005)$ \\
\hline Time (c) & 161.269 & 1 & $234.08^{* * *}$ & Time (c) & $-.082(.007)$ \\
\hline $\operatorname{Time}^{2}$ (c) & 68.072 & 1 & $98.80^{* * *}$ & Time $^{2}(\mathrm{c})$ & $.002(.000)$ \\
\hline Negative & 4.176 & 1 & $6.06^{*}$ & Negative & $-.144(.058)$ \\
\hline Neg*Time & 18.868 & 1 & $27.39 * * *$ & Neg*Time & $.042(.008)$ \\
\hline Neg $^{*}$ Time $^{2}$ & 20.400 & 1 & $29.61 * * *$ & Neg*Time $^{2}$ & $-.001(.000)$ \\
\hline Residual & 5071.377 & 7361 & & Constant & $18.199(.074)$ \\
\hline Total & 5630.792 & 7405 & & $\overline{R s q}$ & .099 \\
\hline
\end{tabular}


Table 4. Within-Respondent ANCOVA: Heartrate

\begin{tabular}{|c|c|c|c|c|c|}
\hline \multicolumn{4}{|c|}{ ANCOVA } & \multicolumn{2}{|c|}{ OLS Regression } \\
\hline & Partial SS & df & $\mathrm{F}$ & & Raw Coef \\
\hline Model & 954600.833 & 44 & $566.25^{* * *}$ & & \\
\hline Respondent & 935232.136 & 38 & $642.35^{* * *}$ & & \\
\hline Order (c) & 1714.909 & 1 & $46.10^{* * *}$ & Order (c) & $-.266(.040)$ \\
\hline Time $(c)$ & 1027.469 & 1 & $26.82^{* * *}$ & Time (c) & $-.266(.051)$ \\
\hline $\operatorname{Time}^{2}(\mathrm{c})$ & 768.560 & 1 & $20.06^{* * *}$ & $\operatorname{Time}^{2}(\mathrm{c})$ & $.007(.002)$ \\
\hline Negative & 1108.093 & 1 & $28.92^{* * *}$ & Negative & $-2.355(.438)$ \\
\hline Neg*Time & 537.598 & 1 & $14.03^{* * *}$ & Neg*Time & $.223(.060)$ \\
\hline Neg $^{*}$ Time $^{2}$ & 514.596 & & $13.43^{* * *}$ & Neg $^{*}$ Time $^{2}$ & $-.007(.002)$ \\
\hline Residual & 279618.277 & 7298 & & Constant & $71.915(.554)$ \\
\hline Total & 1234219.11 & 7342 & & $\mathrm{Rsq}$ & .773 \\
\hline
\end{tabular}


Figure 1. Skin Conductance and Heartrate: Respondent 12

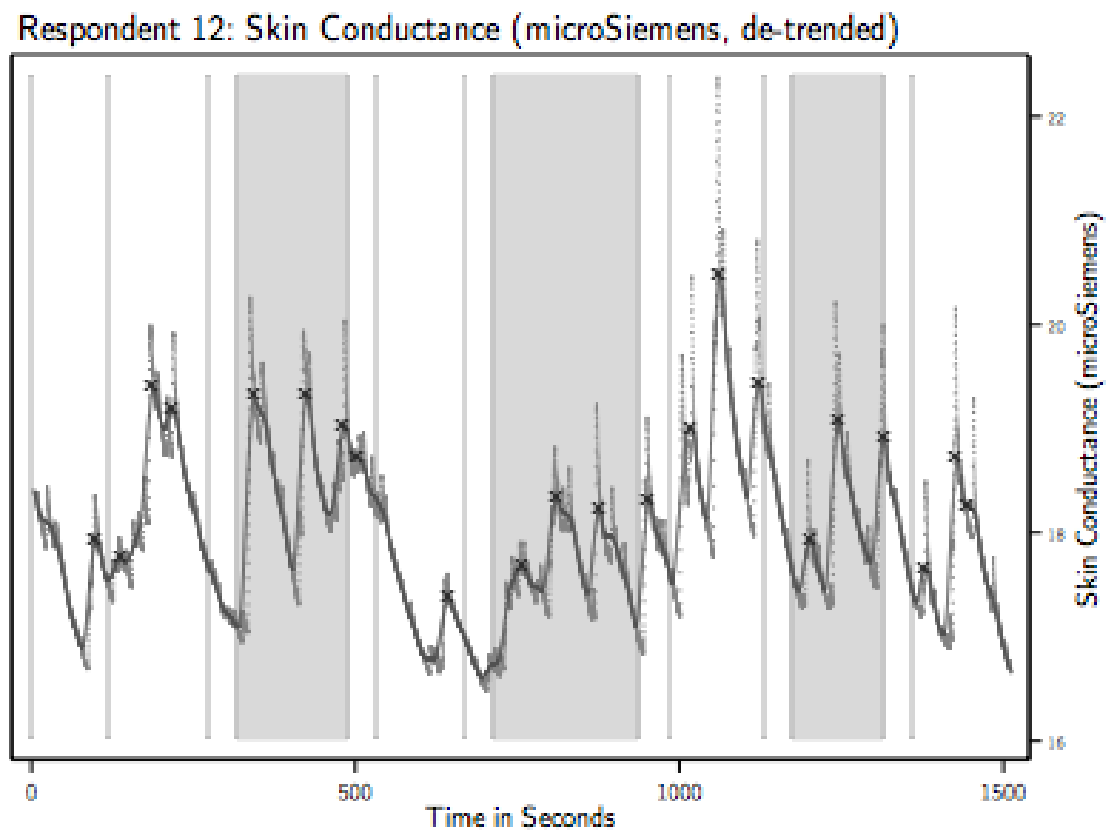

Respondent 12: Heartrate (beats/minute)

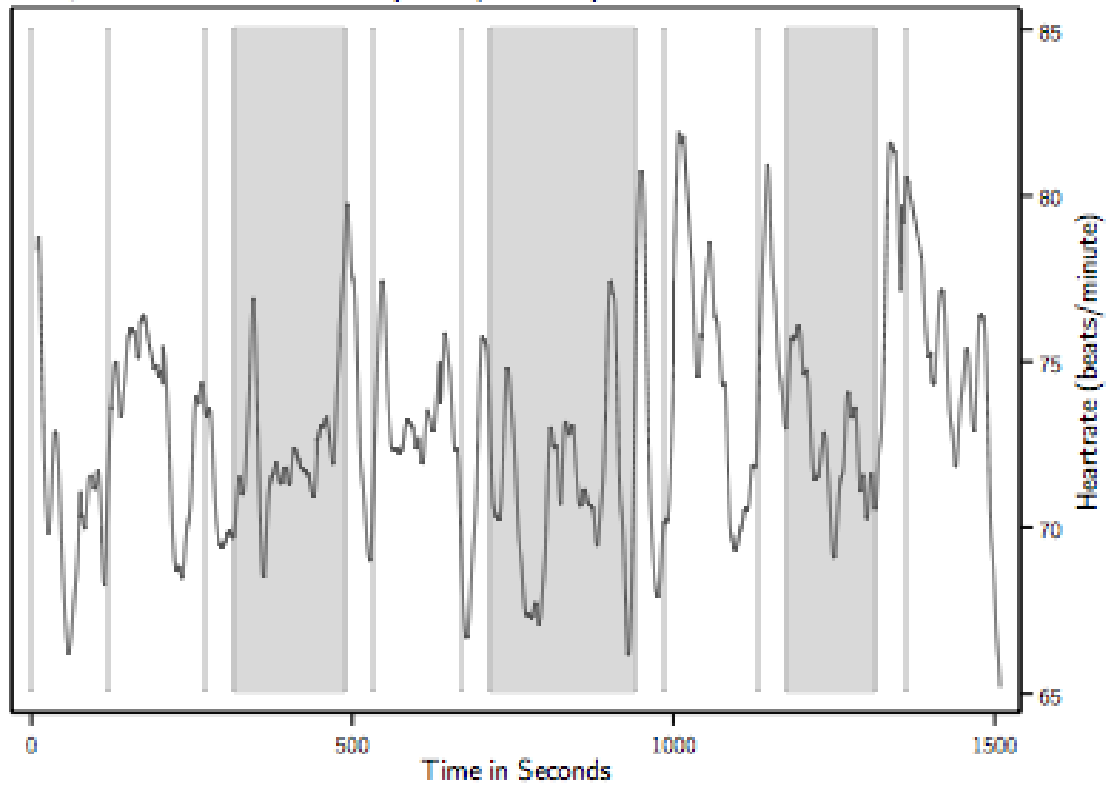


Figure 2. Skin Conductance and Heartrate: Respondent 44

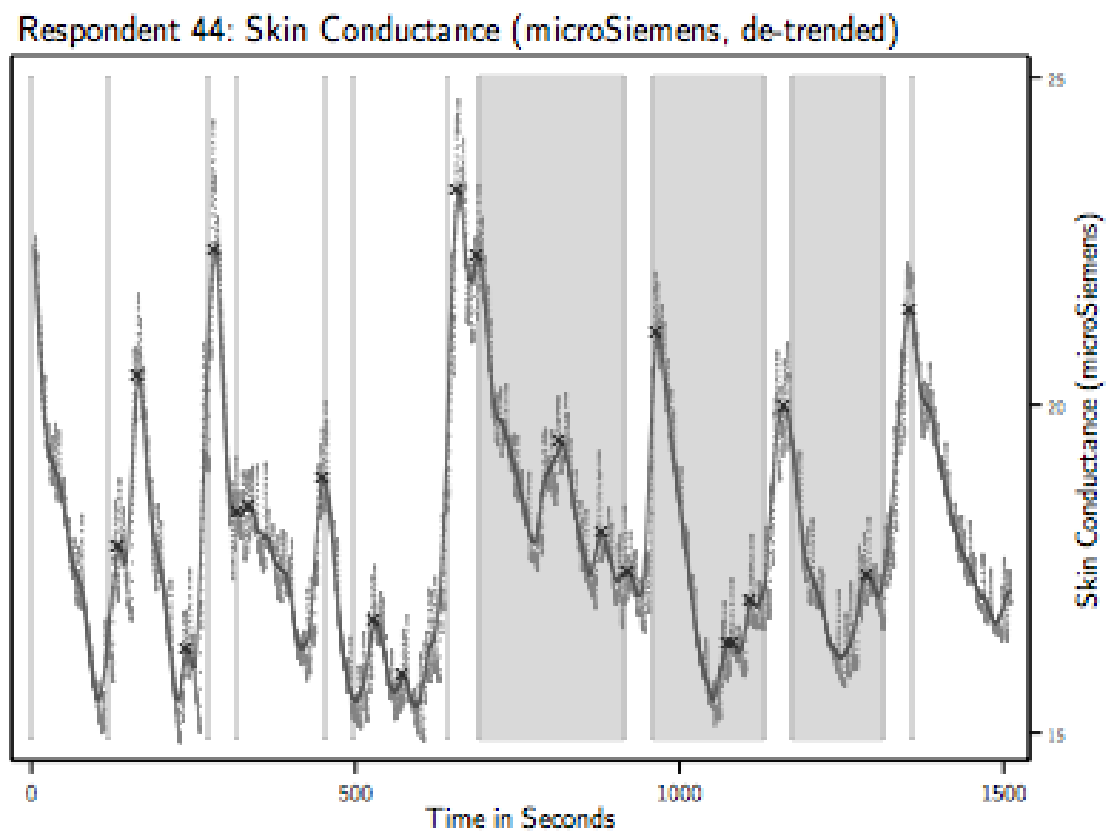

Respondent 44: Heartrate (beats/minute)

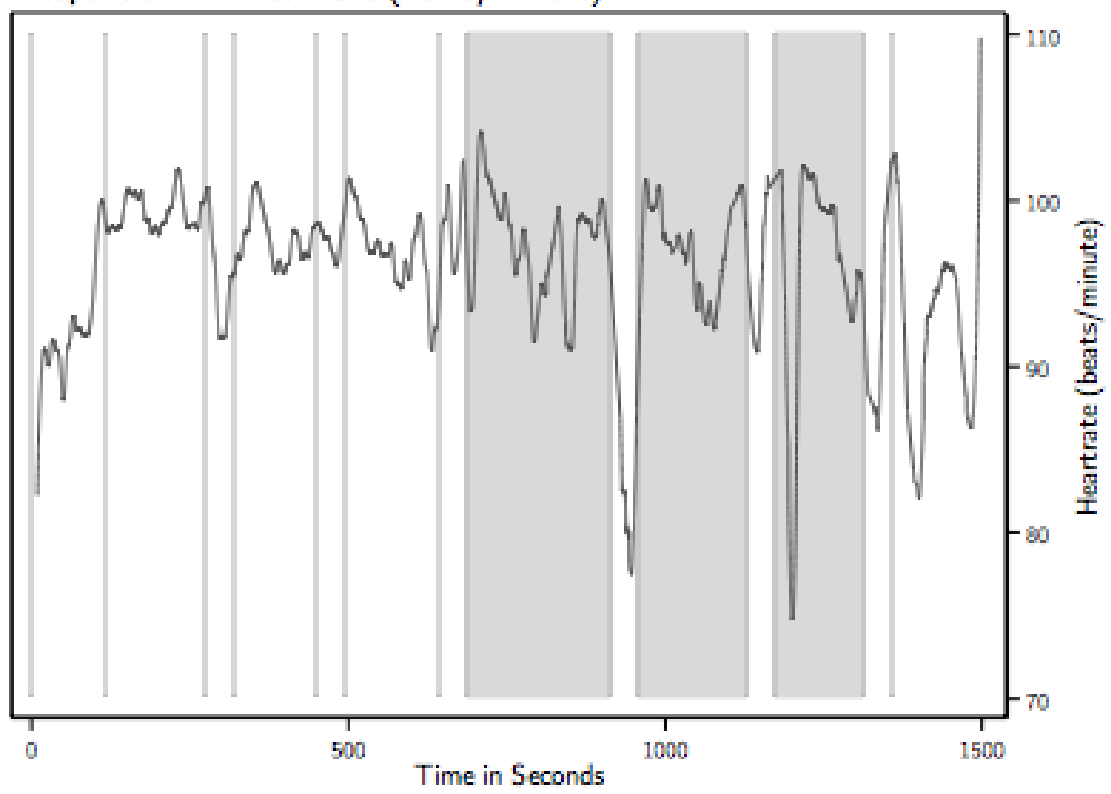


Figure 3. Predicted Values, Skin Conductance and Heartrate
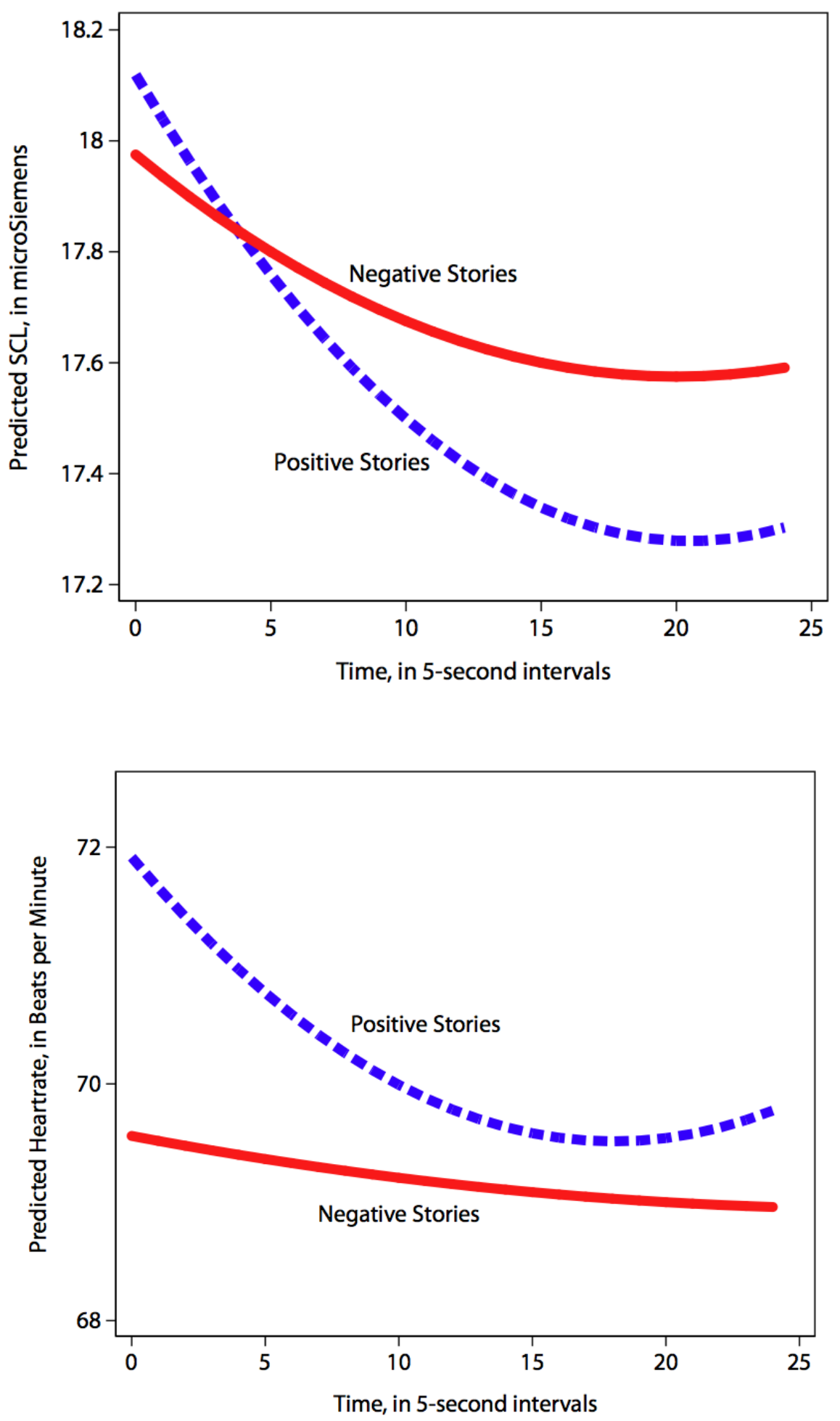